\title{
Sprawozdanie z konferencji „Mazowsze Północne w walce o Niepodległość i ostateczny ksztalt granic Rzeczpospolitej Polskiej w latach 1914-1921" (Plock, 27 października 2018 r.)
}

27 października 2018 r. w Sali Barokowej Opactwa Pobenedyktyńskiego w Płocku odbyła się kolejna z konferencji naukowych, organizowanych od wielu lat przez Stowarzyszenie Rodzin Katolickich Diecezji Płockiej, we współpracy z Wydziałem ds. Rodzin Kurii Diecezjalnej Płockiej. W jubileuszowym roku 100. rocznicy odzyskania niepodległości przez Polskę tematem spotkania były kwestie związane z kształtowaniem się granic Rzeczypospolitej około 1918 r., jak również sprawa udziału różnych grup społecznych w walkach o wolność i powrót Polski na mapy świata.

Konferencję rozpoczął ks. dr Wojciech Kućko, Dyrektor Wydziału ds. Rodzin i asystent Stowarzyszenia Rodzin Katolickich Diecezji Płockiej, a także pracownik badawczo-dydaktyczny Wydziału Studiów nad Rodziną UKSW w Warszawie, który po powitaniu zebranych i przedstawieniu uczestników wprowadził wszystkich obecnych w tematykę spotkania. Przypomniał fakt jubileuszu stulecia niepodległości oraz postać św. Stanisława Kostki, patrona Polski, diecezji płockiej oraz dzieci i młodzieży, w roku 450. rocznicy jego śmierci. Ks. Kućko podkreślił także, że w 1867 r., podczas kanonizacji św. Jozafata Kuncewicza, bł. Pius IX ofiarował Polakom świecę i poprosił, by została zapalona w wolnej Warszawie. Po raz pierwszy zapłonęła w 1918 r. w wolnej Polsce, potem 3 czerwca 2018 r., w czasie Święta Dziękczynienia, a kolejny raz - 11 listopada 2018 r. Z okazji rocznicy odzyskania niepodległości, z inicjatywy Lasów Państwowych - Nadleśnictwa Gostynin, Łąck i Płock oraz we współpracy z Wydziałem ds. Rodzin Kurii Płockiej ponad 70 parafii i instytucji z terenu diecezji płockiej otrzymało Dęby Niepodległości wraz z okolicznościową tablicą i certyfikatem.

Pierwszą prelekcję zatytułowaną Duchowieństwo diecezji płockiej w walce o niepodległość Polski zaprezentował ks. prof. dr. hab. Michał Marian Grzybowski z Uniwersytetu Kazimierza Wielkiego w Bydgoszczy. Zauważył, że walka o niepodległość dokonywała się na wielu frontach: przez modlitwę, sztukę, twórczość i szkołę. Duchowieństwo, podobnie jak nauczyciele czy lekarze, prowadzili pracę organiczną na rzecz zachowania języka i kultury polskiej. Ks. Grzybowski przypomniał postaci wybitnych przedstawicieli ówczesnego episkopatu na ziemiach 
polskich, m.in. kard. Edmunda Dalbora, prymasa Polski w latach 1915-1926, oraz kard. Aleksandra Kakowskiego, urodzonego w Dębinach w diecezji płockiej, prymasa Królestwa Polskiego w latach 1925-1938.

Główną częścią wystąpienia badacza dziejów Kościoła na Mazowszu było omówienie życia pięciu płockich duchownych, którzy włożyli znaczący wkład dla podtrzymywania ducha narodowego i zmagań o wolność Polaków. Pierwszym był ks. prał. Antoni Julian Nowowiejski, późniejszy biskup płocki w latach 1908-1941. Ten rzutki duchowny podsunął ordynariuszowi, bp. Apolinaremu Wnukowskiemu, myśl o spotkaniach biskupów z Kongresówki w Płocku. Tolerancyjny ukaz carski z 1905 r., dzięki któremu zyskano na ziemiach polskich pewne swobody, także religijne, dał zielone światło dla realizacji tej idei. Ks. Nowowiejski występował w charakterze konsultora, a potem obrano go sekretarzem spotkań (w latach 1906-1925). Nazywany był „seniorem episkopatu polskiego”. Został zamordowany w obozie w Działdowie, kiedy miał 83 lata. Zajmował się sprawami społecznymi i oświatowymi. W czasie I wojny światowej, gdy nie odbywano wizytacji, apelował o pomoc dla głodujących i bezrobotnych, a potem o szkolnictwo. Wiedział, że na terenie Mazowsza analfabetyzm był ogromny. Wielu księży zakładało szkoły, czasem jednoodziałowe. Biskup prosił, ale kapłani sami wyczuwali intuicyjnie taką potrzebę i tworzyli te instytucje.

Drugą postacią, przedstawioną przez ks. Grzybowskiego, był ks. prał. Adolf Piotr Szelążek (1865-1950). Kończył seminarium płockie, był zdolny, po Akademii Duchownej w Petersburgu otrzymał świadectwo, że „to nie Szelążek, a Dukacik”. Jako pracownik kurii i profesor Seminarium, gdzie wykładał prawo kanoniczne, socjologię, filozofię, łacinę i wymowę kościelną, okazał się erudytą i praktykiem. Z bp. Józefem Elizeuszem hr. Szembekiem przygotowywał materiał do ukazu z 1905 r. Przez 10 lat jako profesor i rektor Seminarium (1909-1918) angażował się także w sprawy społeczno-polityczne. Był członkiem i prezesem Płockiego Towarzystwa Dobroczynności. Zorganizował Sale Pracy św. Józefa dla Chłopcówszkołę dla stolarzy i krawców. Organizował ochronki, Stowarzyszenie Katolików Chrześcijańskich, działał Polskim Związku Katolickim, Płockim Towarzystwie Opieki nad Wychodźcami (sformułował określenie „obieżysastwo” - wyjazd na pracę do Prus). Ks. Grzybowski zauważył, że w czasie I wojny światowej z Mazowsza wyjechało 40.000 ludzi. Z własnych pieniędzy ks. Szelążek wspierał edukację zdolnej młodzieży. Marcin Kacprzak, późniejszy profesor i medyk, patron Szpitala na Winiarach, w którego wykształceniu pomagał ks. Szelążek, ufundował gabinet dentystyczny w Seminarium. W 1925 r. ks. Szelążek został mianowany biskupem łuckim, a w 1945 r. NKWD przywiozło go do Przemyśla. Prowadzony jest jego proces beatyfikacyjny. 
Ks. prof. Grzybowski omówił jeszcze postaci trzech kapłanów płockich. Najpierw ks. Adama Maciejowskiego (1874-1919), wybitnego mówcy, gorącego patrioty, który za cykl kazań, a zwłaszcza za mowę z racji śmierci H. Sienkiewicza, nazwany został ,płockim Skargą". Inni duchowni, patrioci i społecznicy tamtego czasu, to ks. Ignacy Lasocki (1860-1933), którego dziełem była płocka Stanisławówka, jak również ks. Ignacy Charszewski (1869-1940), publicysta, autor ok. 1000 publikacji.

Drugą prelekcję, zatytułowaną Jesteśmy wolni! Plock 11 listopada 1918 r., wygłosiła dr Magdalena Bilska-Ciećwierz z Muzeum Mazowieckiego w Płocku, ukazując klimat społeczny i polityczny na ziemiach płockich przed odzyskaniem niepodległości przez Polskę. Opisała sytuację religijną miasta, które było stolicą biskupstwa katolickiego, mieściła się tu cerkiew prawosławna, kościół ewangelicki, główna świątynia mariawitów oraz dwie synagogi. Prelegentka przypomniała, że w Płocku działały dwie elektrownie, wodociągi, kilka fabryk narzędzi i maszyn rolniczych, teatr, trzy kina. Działalność naukowa była skupiona wokół Towarzystwa Naukowego Płockiego i Seminarium Duchownego, a oświata rozwijała się w dwóch gimnazjach męskich, dwóch gimnazjach żeńskich. Dr Bilska-Ciećwierz opisała także czas I wojny światowej, kolejne wejścia wojsk rosyjskich i niemieckich, które opanowywały miasto, sytuację biedy, bezrobocia i nędzy moralnej tamtego czasu. Ważnymi wydarzeniami, zapowiadającymi zmiany, było świętowanie rocznic patriotycznych: w 1916 r. - 125. rocznica ogłoszenia Konstytucji 3 Maja, obchody związane ze śmiercią Henryka Sienkiewicza w 1916 r. czy 100. rocznica śmierci Tadeusza Kościuszki w 1917 r. W dalszej części prelegentka ukazała atmosferę dni 11 i 12 listopada 1918 r., kończąc wystąpienie słowami Marii Macieszyny z Pamiętnika płocczanki: „Jesteśmy wolni! Niemców nie ma! / Zdawałoby się, że naokół biją jakieś radosne dzwony. / Zdawałoby się, że nastało jakieś niezmiernie uroczyste święto!”.

Ostatnie wystąpienie zaprezentował nadleśniczy Jacek Liziniewicz z Nadleśnictwa Gostynin, który opowiedział o miejscach pamięci na terenie tegoż nadleśnictwa, położonego na południe od Wisły. Przypomniał fakty historyczne na temat walk w lasach, jak również zaprezentował obecny stan tych miejsc pamięci. Lasy gostynińskie kryją ślady powstania styczniowego w następujących miejscowościach: Gaśno (pomnik z 1998 r., na miejscu wcześniejszego sprzed II wojny światowej), Teodorów i Zuzinów. Kolejne omówione przez nadleśniczego Liziniewicza miejsca dotyczyły czasów okupacji niemieckiej w czasie II wojny światowej. Są wśród nich następujące miejscowości: Kraśnica (1940 r.), Drzewce (1941 r.), cmentarz przy Szpitalu Psychiatrycznym w Gostyninie (1943 r.). We wsi Lipianki znajduje się zaś obelisk upamiętniający pacyfikację wsi oraz ofiary deportacji w głąb III Rzeszy. W 2005 r. została zaprowadzona uprawa leśna, poświęcona pamięci św. Jana Pawła II. Nadleśniczy Liziniewicz zakończył swoje 
wystąpienie przypomnieniem historii odnalezienia grobów gostynińskich Żydów, znalezionych jesienią 2010 r. na leśnej drodze przy trasie Gostynin - Skrzany przez Jana Żuchowskiego oraz informacjami na temat ekshumacji żołnierzy niemieckich, przeprowadzonej w uroczysku Białe Błota na Terenie leśnictwa Szczawin w 2017 r.

Podsumowania obrad dokonał Witold Wybult, prezes Stowarzyszenia Rodzin Katolickich Diecezji Płockiej, dziękując wszystkim za udział, a także za patronat honorowy nad sympozjum, którego udzielili: Biskup Płocki Piotr Libera, Prezydent Miasta Płocka Andrzej Nowakowski oraz Starostwo Płockie. Ostatnim punktem spotkania był koncert patriotyczny w wykonaniu zespołu „Moja Rodzina” z Glinojecka.

ks. dr Wojciech Kućko

Wydziat Studiów nad Rodzina - UKSW w Warszawie 